Article published as:

Guo, X., Marinova, D., Hong, J. (2013) China's shifting policies towards sustainability: a low-carbon economy and environmental protection, Journal of Contemporary China, 22(81): 428-445

\title{
China's Shifting Policies towards Sustainability: A Low-carbon Economy and Environmental Protection
}

Xiumei Guo, Dora Marinova and Jin Hong ${ }^{*}$

China is currently not only the most populous country on earth, but also the world's largest greenhouse gas (GHG) emitter. As China's population growth continues contributing to the overall global population increase, the country remains a significant player in the global problems related to climate change. The Chinese government however has recognized that a low-carbon economy is in the country's long-term economic and social interests and this is now a key part of its national development strategy. This paper examines the evolution of policies for sustainability in China and explores their compositions, functions and operational mechanisms. Some emerging features and trends of China's development model are examined arguing that they represent a clear shift towards sustainability. Further problems and challenges associated with this change and how they impact on China's policies and strategies are also discussed.

\section{Introduction}

\footnotetext{
* Xiumei Guo is a research fellow at the Curtin University Sustainability Policy (CUSP) Institute in Australia. She completed her PhD examining Chinese immigration in Australia and her research interests are in the area of demography, economic development, energy efficiency and sustainability studies with a focus on China. Xiumei is currently conducting research for the Australian Research Council on energy efficiency, economic growth and the environment in China. Dora Marinova is a professor of sustainability and deputy director of CUSP. Her current research relates to the role of new technologies for sustainability, technology policy and economic development in Australia and China. She has more than 300 publications and has supervised to completion more than $40 \mathrm{PhD}$ students. Jin Hong is an associate professor in the Management School of the University of Science and Technology of China and in charge of the School's postgraduate Masters program. He was a visiting fellow at the Institute for Sustainability and Technology Policy, Murdoch University in 2007-2008 and Lund University in Sweden in 2010. His research is on China's science and technology policy, economic development and sustainability.

The first two authors want to acknowledge the financial support of the Australian Research Council. The third author wishes to acknowledge the financial support of the National Natural Science Foundation of China (71172213) and the Ministry of Education's Humanities and Social Sciences Project (09YJA630153).
} 
Article published as:

Guo, X., Marinova, D., Hong, J. (2013) China's shifting policies towards sustainability: a low-carbon economy and environmental protection, Journal of Contemporary China, 22(81): 428-445

China is the world's largest developing country with a fast growing economy whose strength managed to survive the 1997 Asian Financial Crisis ${ }^{1}$ and was the country to recover very quickly from the 2008 Global Financial Crisis. In doing so, its main task has been to achieve economic prosperity and increase its people's quality of life. Following the nation's economic reform and open door policy introduced in 1978, over the last three decades China has enjoyed high economic growth. More recently however, the country also attracted a lot of global attention from environmentalists for becoming in 2007 the top global greenhouse gas (GHG) emitter. ${ }^{2}$ Its carbon dioxide $\left(\mathrm{CO}_{2}\right)$ emissions have almost tripled between 1990 and 2007. ${ }^{3}$ With successive Chinese governments concentrating on economic growth and decentralization challenges ${ }^{4}$, not enough attention has been paid to environmental issues. The country's fast industrialization and urbanization have continued to significantly contribute to severe environmental problems related to climate change as well as cause widespread environmental deterioration.

Recently the Chinese government acknowledged these serious concerns and recognized that developing a low-carbon economy is in the country's long-term economic and social interest. Increased environmental education and awareness have played a major role in this change. These are now key parts of China's national development strategy and plan confirming that the country is making a shift towards a more sustainable development model. This transformation has implications for the introduction of better policies for achieving low-carbon economic growth in China and allowing the right balance between economic prosperity, quality of life, social justice and environmental protection.

\footnotetext{
${ }^{1}$ Lowell Dittmer, 'The Asian Financial Crisis and the Asian Developmental State: Then Years After', Asian Survey 47, (2007), pp. 829-833.

${ }^{2}$ See 'China overtakes US as world's biggest CO2 emitter'. Accessed 26 October 2012. http://www. guardian.co.uk/environment/2007/jun/19/china.usnews.

${ }^{3}$ International Energy Agency, $\mathrm{CO}_{2}$ Emissions from Fuel Combustion Highlights (Paris: OECD/IEA, 2009).

${ }^{4}$ Alfred M. Wu, 'How does Decentralized Governance Work? Evidence from China', Journal of Contemporary China, 22(81), (2013), current issue pp.??
} 
Article published as:

Guo, X., Marinova, D., Hong, J. (2013) China's shifting policies towards sustainability: a low-carbon economy and environmental protection, Journal of Contemporary China, 22(81): 428-445

\section{Economic Growth and Carbon Emissions in China}

The Chinese economy has been growing at an average rate of $10 \%$ per annum since 1978 when the economic reform program was originally initiated. ${ }^{5}$ At the moment, China is still Asia's fastest-growing economy with GDP (see Figure 1) estimated to rise by $8.8 \%$ in $2011 .^{6}$ Not only has the country's fast expanding economy become more powerful, with GDP raising from 362 billion yuan in 1978 to 39.8 trillion yuan in 2010, but also individuals on average have become richer, with GDP per capita increasing from 379 yuan in 1978 to 29,701 yuan in 2008. ${ }^{7}$ Nevertheless, China still remains a developing country with much lower per capita GDP than the West (see Figure 2).

[Insert Figure 1 here]

[Insert Figure 2 here]

In 2006, the Chinese government realized that the staged approach of economic growth first and pollution abatement second, has resulted greatly in large energy consumption that causes major environmental concern. For example, as the largest coal consumer, China allowed for many decades crude coal to be burned without being processed. ${ }^{8}$ Figure 3 shows that China's total GHG emissions have grown exponentially to become the highest in the

\footnotetext{
${ }^{5}$ Yanrui Wu, Economic Growth, Transition and Globalization in China (Cheltenham, UK and Northampton, MA, USA: Edward Elgar, 2006).

${ }^{6}$ United Nations Development Programme (UNDP) China, China Human Development Report 2009/10: China and a Sustainable Future Towards a Low Carbon Economy and Society (Beijing: China Publishing Group Corporation, China Translation \& Publishing Corporation, 2010).

${ }^{7}$ National Bureau of Statistics of China, China Statistical Yearbook (Beijing: China Statistics Press, 2011).

${ }^{8}$ Chinese Government's Official Web Portal, Energy Consumption Major Environment, 2006. Accessed 26 October 2012. http://www.gov.cn/english/2006-04/13/content_252597.htm.
} 
Article published as:

Guo, X., Marinova, D., Hong, J. (2013) China's shifting policies towards sustainability: a low-carbon economy and environmental protection, Journal of Contemporary China, 22(81): 428-445

world. Only in the previous $11^{\text {th }}$ Five-Year Development Plan (2006-2010) has China made the environment a priority. ${ }^{9}$ This old staged policy focus is now seen as incorrect decisionmaking about use of resources and related environmental implications. UNDP China argues that there is a danger that China's three decades of economic achievements may be at risk, if climate change impacts are not adequately addressed in the country. ${ }^{10}$

[Insert Figure 3 here]

The structure of China's economy has significantly transformed since the $10^{\text {th }}$ FiveYear Plan period (2000-2005) and is now much less dependent on agriculture, with manufacturing boom in the 2000s and substantial increase in the services sector. Rapid economic growth was achieved through industrialization and urbanization at the cost of resources and the natural environment. The level of carbon emissions depends directly on the structure of the economy and used technologies. With China's economic development still being at a stage of industrialization and urbanization (with less contribution from high-tech industries), it has sustained an increased demand for energy, and consequently, an inevitable growth in $\mathrm{CO}_{2}$ emissions. ${ }^{11}$

However, by world standards China's per capita $\mathrm{CO}_{2}$ emissions are just above the average (see Figure 4). Despite this, due to the size of its population its global impact is enormous. In 2006, the Chinese Government realized the timely need for a change in the

\footnotetext{
${ }^{9}$ Chinese Government's Official Web Portal, The $11^{\text {th }}$ Five-Year Plan. Accessed 26 October 2012. http://www.gov.cn/english/special/115y_rs.htm.

${ }^{10}$ United Nations Development Programme (UNDP) UNDP in Action 2009/2010: Delivering on Commitments. Accessed 26 October 2012. http://www.undp.org/publications/UNDPaction2010/report.shtml.

${ }^{11}$ United Nations Development Programme (UNDP) China, Human Development Report 2009/10 - Key Findings, China and a Sustainable Future Towards a Low Carbon Economy and Society, 2009. Accessed 26 October 2012. http://content.undp.org/go/cms-service/stream/asset/?asset_id=2471266.
} 
Article published as:

Guo, X., Marinova, D., Hong, J. (2013) China's shifting policies towards sustainability: a low-carbon economy and environmental protection, Journal of Contemporary China, 22(81): 428-445

economic growth model. It was recognized that China's development needs to become more sustainable and reduce the heavy reliance on resources. ${ }^{12}$

[Insert Figure 4 here]

The $11^{\text {th }}$ Five-Year Plan gave more importance to environmental protection. For example, it set an energy intensity reduction target of $20 \%$ and a major pollution reduction target of $10 \%$ by 2010 against the 2005 level. Total discharge of major pollutants was expected to be cut down by $10 \%$ in five years (see Table 1). The effective action of the amended Energy Conservation Law in 2008 further increased the pressure for China's industries to improve energy efficiency. ${ }^{13}$ A year later in 2009, China announced to the world its first quantified target on reducing the intensity of CO2 emissions per unit of GDP by 40$45 \%$ by 2020 against the 2005 level (which was $\left.2.1 \mathrm{kgCO}_{2} / 2005 \mathrm{US} \$\right)^{14}$. This commitment was also incorporated in the official government policies. The target included in the $12^{\text {th }}$ Five-Year Plan is for $17 \%$ reduction for the $2011-2015$ period $^{15}$. Further targets included in the plan are the overall energy intensity to be reduced by $16 \%$ and the share of non-fossil energy to be increased to $11 \%$ of total energy use ${ }^{16}$. Figure 5 shows that China is already steadily decreasing its $\mathrm{CO}_{2}$ emission intensity.

\footnotetext{
${ }^{12}$ National Development and Reform Commission (2006), The 11th Five-Year Plan: Targets, Paths and Policy Orientation, (MA Kai, Minister Speech). Accessed 26 October 2012. http://www.gov.cn/english/200603/23/content_234832.htm.

${ }^{13}$ Urda Eichhorst and Daniel Bongardt, Towards Cooperative Policy Approaches in China-Drivers for Voluntary Agreements on Industrial Energy Efficiency in Nanjing, Energy Policy, 37, (2009), pp. 1855-1865.

${ }^{14}$ International Energy Agency, CO2 Emissions from Fuel Combustion. Accessed 26 October 2012. http://www.iea.org/publications/freepublications/publication/name,4010,en.html

15 Joanna Lewis, 'Energy and Climate Goals of China's 12th Five-Year Plan', 2011. Accessed 26 October 2012. http://www.pewclimate.org/international/factsheet/energy-climate-goals-china-twelfth-five-year-plan. ${ }^{16}$ Ibid.
} 
Article published as:

Guo, X., Marinova, D., Hong, J. (2013) China's shifting policies towards sustainability: a low-carbon economy and environmental protection, Journal of Contemporary China, 22(81): 428-445

[Insert Table 1 here]

[Insert Figure 5 here]

Climate change is regarded as one of the greatest environmental challenges facing the global community today with the global GHG emissions increasing more than four-fold in the last half of the twentieth century. ${ }^{17}$ China's future role in cutting down global carbon emissions is expected to become even more significant and it is important to know how the country is responding to these environmental challenges.

\section{Environmental Issues and Policy Shift in China}

In addition to becoming a major global contributor of GHG emissions, China's own natural environment has suffered severe deterioration during the time when the country's governments were concentrating on economic growth and private institutions were pursuing financial benefits. Serious concerns about the impact of China's economic growth on its environment have been raised since the $1990 \mathrm{~s}^{18}$. Despite this, air pollution in major cities continues to be an alarming issue. ${ }^{19}$ Problems with access to clean water and eutrophication of major water basins such as Chao Lake and Tai Lake are attracting increasing domestic and international attention. ${ }^{20,21}$ Another example is the large mass of floating green algae that

\footnotetext{
${ }^{17}$ Department of Trade and Industry, Energy: Its Impact on the Environment and Society, 2006. Accessed 7 August 2007. www.dti.gov.uk.

${ }^{18}$ Wan Ming, China's Economic Growth and The Environment in the Asia-Pacific Region, Asian Survey, 38 (1998), pp. 365-378.

${ }^{19}$ United Nations Environment Programme (UNEP), Expo 2010: Shanghai, China, 2009. Accessed 26 October 2012. http://www.unep.org/publications/contents/pub_details_search.asp?ID=4040.

${ }^{20}$ Jin Hong, Xiumei Guo, Marinova Dora and Dingtao Zhao. (2007) Analysis of Water Pollution and Ecosystem Health in the Chao Lake Basin, China, MODSIM 2007 International Congress on Modelling and Simulation, Modelling and Simulation Society of Australia and New Zealand, Christchurch, 2007, pp. 1966-1972.

${ }^{21}$ Yanrui Wu, Regional Environmental Performance and Its Determinants in China, China and World Economy, 18, (2010), pp. 73-89.
} 
Article published as:

Guo, X., Marinova, D., Hong, J. (2013) China's shifting policies towards sustainability: a low-carbon economy and environmental protection, Journal of Contemporary China, 22(81): 428-445

came ashore covering a 400sqm area on the beach in Qingdao, a popular coastal tourist destination; the algae consumes large amounts of oxygen, threatening marine life. ${ }^{22}$ The growing population in sprawling cities challenges the urban standards of energy efficiency and the infrastructure required; they are also impacting on natural habitats causing loss of biodiversity. China's coal-based economy is contributing towards increasing health related risks, such as respiratory diseases and lung cancer.

Despite many environmental protection policies and regulations being put in place ${ }^{23}$, concern for China's environmental issues keeps growing due to the fast economic and human development, ${ }^{24}$ associated with the country's rapid industrialization and urbanization. ${ }^{25} \mathrm{~A}$ major reason for this is the difficulty in implementing and controlling compliance with environmental legislation ${ }^{26}$. Uncontrolled and improper land use causes soil erosion, land loss and deteriorating urban environments due to the growing number of factories, vehicles and a lack of enforcement of the environmental regulations and laws. ${ }^{27}$ In addition, longer periods of low or no flow in China's major rivers are a common phenomenon due to residential and industrial wastes and poor management of water. ${ }^{28}$ The intensity of the exploitation of natural resources and poor technology and management in China cause the

\footnotetext{
${ }^{22}$ China Daily, Green Algae Clean-up Underway in Tourist City, 2010. Accessed 26 October 2012. www.chinadaily.com.cn/photo/2010-06/29/content_10036845.htm.

${ }^{23} \mathrm{~A}$ good analysis of environmental priorities in government legislation in China is provided in Xibing Huang X, Dingtao Zhao, Colin Brown, Yanrui Wu and Scott Waldron, 'Environmental issues and policy priorities in China: A content analysis of government documents', China: An International Journal, 8, (2010), pp. 220-246.

${ }^{24}$ United Nations Development Programme (UNDP) China, Human Development Report 2009/10 - Key Findings, China and a Sustainable Future Towards a Low Carbon Economy and Society, 2009. Accessed 26 October 2012. http://content.undp.org/go/cms-service/stream/asset/?asset_id=2471266.

${ }^{25}$ Guanzhong James Wen, “Urbanization and Population Relocation”, in Globalization of the Chinese Economy, ed. Shangjin Wei, Guanzhong James Wen and Huizhong Zhou (Cheltenham, UK and Northampton, MA, USA: Edward Elgar, 2002, pp. 134-152).

${ }^{26}$ See for example, Xiaoying Ma and Leonard Ortolano, Environmental Regulation in China: Institutions, Enforcement, and Compliance (Lanham, Maryland and Oxford, England: Rowman \& Littlefield, 2000).

${ }^{27}$ Xiumei Guo and Dora Marinova, Population Ageing and Sustainability in China: Comparisons with Australia, Proceeding of the International ACESA Conference on Emerging China: Internal Challenges and Global Implications, 13-14 July 2006, Victoria University.

${ }^{28}$ Jin Hong, Xiumei Guo, Dora Marinova, and Dingtao Zhao, Analysis of Water Pollution and Ecosystem Health in the Chao Lake Basin, China, MODSIM 2007 International Congress on Modelling and Simulation, Modelling and Simulation Society of Australia and New Zealand, Christchurch, 2007, pp. 1966-1972
} 
Article published as:

Guo, X., Marinova, D., Hong, J. (2013) China's shifting policies towards sustainability: a low-carbon economy and environmental protection, Journal of Contemporary China, 22(81): 428-445

increasing amount of pollutants produced and their rapid spread from urban to rural areas nationwide. Consequently, environmental pollution and ecological destruction are widespread and urgent measures are needed to increase the level of environmental awareness and action.

The government has been an active player in putting environmental policies in place (see Table 2), and related policies have been also undergoing an evolutionary process along with economic development ${ }^{29}$. It officially started to pay attention to the country's environment in its $6^{\text {th }}$ FYP (1981-1985), which is the time after China opened its doors to the world and initiated the economic reform and one-child population policy. In 1983, environmental protection became state policy with the environmental impact assessment system being the basis for dealing with environmental pollution and ecological damage through legal means. By 2003, China has promulgated seven environmental protection laws and over 120 regulations to ensure a better protection of the ecology for the world's largest population. ${ }^{30}$ The People's Republic of China’s Environmental Impact Assessment Law was introduced in 2003 and the environmental impact assessment system was extended to all construction projects. In order to adequately implement environmental impact assessment, a professional assessment team was established, consisting of professional and technical staff. ${ }^{31}$ Methods of enforcing environmental legislation include discharge fees, surcharge fees, fines and administrative sanctions, and pollutant discharge activity is subject to a discharge permit. ${ }^{32}$ Self-governance at a village level ${ }^{33}$ in collaboration with local and central

\footnotetext{
${ }^{29}$ A detailed analysis of the evolution of science and technology policies in China's biotechnology and pharmaceutical sector, for example, is provided in Kai Wang, Jin Hong, Dora Marinova, Liang Zhu, Evolution and Governance of the Biotechnology and Pharmaceutical Industry of China, Mathematics and Computers in Simulation, 79, (2009), pp. 2947-2956.

${ }^{30}$ Embassy of the People's Republic of China in Australia, China Enforces Environment Laws in Economic Development, 2003. Accessed 26 October 2012. http://au.china-embassy.org/eng/jmhz/t46236.htm.

${ }^{31}$ State Council Information Office of the PRC The Environmental Protection in China (1996-2005), Beijing, 2006 (in Chinese). Accessed 26 October 2012. http://www.gov.cn/zwgk/2006-06/05/content_300288.htm. ${ }^{32}$ U.S. Department of Commerce, Water Supply and Wastewater Treatment Market in China (Washington, D.C.: International Trade Administration, 2005).

${ }^{33}$ Jie Chen, Popular Support for Village Self-government in China, Asian Survey, 45, (2005), pp. 865-885.
} 
Article published as:

Guo, X., Marinova, D., Hong, J. (2013) China's shifting policies towards sustainability: a low-carbon economy and environmental protection, Journal of Contemporary China, 22(81): 428-445

government started to also play a major role in supporting environmental control and regulation.

[Insert Table 2 here]

However, the country's implementation of environmental protection regulations was not strengthened significantly until its $10^{\text {th }}$ FYP (2001-2005) period, when the government realized that high consumption of energy during this period led to some environmental protection goals not being met. For example, only 12 out of 20 (60\%) environmental goals set for the $10^{\text {th }}$ Five-Year Plan were met. In addition, the five-year plan stipulated that discharges of sulfur dioxide should be cut by $10 \%$, but compared with the discharge levels from 2000 , the levels of the pollutant increased by $27 \%$ in 2005 . Thermal-power generation, which has exceeded the planned capacities, is considered to be the biggest consumer of coal and hence the largest discharger of sulfur dioxide. For example, according to the plan, the installed capability of thermo-power generation should have been about 400 megawatts in 2005; however the de-facto installed capability was 25\% higher, bringing it up to more than 500 megawatts. Energy consumption and thermo-power generation expansion were considered to be the key factors blamable for the country's failure in sulfur dioxide reductions. ${ }^{34}$

China strengthened the enforcement of environmental legislation further by disciplinary sanctions, civil liability and even criminal liability. ${ }^{35}$ This enabled the country to meet its annual target of closing down outdated coal-fuelled power generating capacity of

\footnotetext{
${ }^{34}$ Chinese Government's Official Web Portal, Facts and figures: China's main targets for 2006-2010, 2006. Accessed 26 October 2012. http://www.gov.cn/english/2006-03/06/content_219504.htm.

${ }^{35}$ US Department of Commerce, Water Supply and Wastewater Treatment Market in China (Washington, D.C.: International Trade Administration, 2005).
} 
Article published as:

Guo, X., Marinova, D., Hong, J. (2013) China's shifting policies towards sustainability: a low-carbon economy and environmental protection, Journal of Contemporary China, 22(81): 428-445

over 10 gigawatts in 2010 (a total of 468 generators in power stations), bringing the total to 71 gigawatts during the $11^{\text {th }}$ Five-Year Plan period. ${ }^{36}$

Although China believes that developed countries have consumed an enormous quantity of world energy resources to complete their industrialization in the past, the country now itself has become a world-class economy and has started to take upon itself the responsibility that comes with it. ${ }^{37}$ The most encouraging step for China was that at the end of the 2009, just before the UN climate change summit in Copenhagen, the State Council executive meeting declared China's voluntary commitment of $40-45 \%$ reduction in the intensity of $\mathrm{CO}_{2}$ emissions per unit of GDP. It was the very first time for China to set quantified targets, which presented its ambition of not only tackling the challenge of climate change, ${ }^{38}$ but also to become a leading world power in the shift towards sustainability. China's future role is expected to be significant to cut down the global carbon emissions as well as reduce the immediate impact on its ecology through exploring and developing a lowcarbon economy.

\section{China's Low-Carbon Economy}

According to the UN, China has "no other choice" but to shift to a low-carbon pathway in order to sustain its current economic growth and meet its future social and economic development targets. ${ }^{39}$ A low-carbon economy refers to an international comparison of

\footnotetext{
${ }^{36}$ Embassy of the People's Republic of China in Australia China meets national target of closing outdated coalfueled power stations, 2010. Accessed 26 October 2012. http://au.chinaembassy.org/eng/zt/ziyuanyuhuanjing/t719451.htm.

${ }^{37}$ World Watch Institute, State of the World: Special Focus: China and India (New York: W.W. Norton \& Company, 2006).

${ }^{38}$ Xinhua Net, China's Commitment of Reduction of the Intensity of Carbon Dioxide Emissions per unit of GDP in 2020 by 40-45 Percent Compared to the 2005, 2009. Accessed 26 October 2012. http://news.xinhuanet.com/politics/2009-11/26/content_12544442.htm.

${ }^{39}$ United Nations Development Programme (UNDP), UNDP in Action 2009/2010: Delivering on Commitments, 2010. Accessed 26 October 2012.

http://www.undp.org/content/india/en/home/library/poverty/undp_in_action_20092010deliveringoncommitment
} 
Article published as:

Guo, X., Marinova, D., Hong, J. (2013) China's shifting policies towards sustainability: a low-carbon economy and environmental protection, Journal of Contemporary China, 22(81): 428-445

carbon intensity per unit of production and "maximizes carbon productivity, improves capacities for adaptation to climate change, minimizes the negative impacts of climate change, improves human development, and accommodates both inter- and intra-generational needs, thereby laying the foundation for sustainable socioeconomic development”. ${ }^{40}$ As distinct to other concepts, such as "green economy”, "ecological economy”, “circular economy" or "industrial ecology" which look at GHG emissions from a domestic environmental perspective, the low-carbon economy aims at meeting global standards. The global importance and the urgency of collaborative actions were recognized at the UN Climate Change Conference of the Parties’ sixteen session (COP16) in Cancún in $2010^{41}$. China, as the top global emitter, is considered to be a significant player and is expected to have a vital role in cutting down the global carbon emissions. Despite the country's attempts to reduce emission intensity, which are well underway, its continuous economic growth has been triggering a sharp increase in the levels of $\mathrm{CO}_{2}$ emissions per capita (see Figure 5).

Developing a low-carbon economy becomes extremely important in the fight to mitigate global warming. China has realized this urgency and has started to formulate policies and measures for developing its low-carbon economy. This is now being endorsed by all level of government. For example, a number of Chinese cities have put forward a vision of transforming to low-carbon cities, and some provinces, such as Baoding of Hubei, Nanchang of Jiangxi ${ }^{42}$ as well as the Shanghai Expo are becoming leaders in adopting this concept. China's commitment so far towards a low-carbon economy is showing the positive side of

\footnotetext{
s.html.

${ }^{40}$ Ibid.

${ }^{41}$ United Nations Framework Convention on Climate Change (UNFCCC) 2010. Outcome of the work of the Ad Hoc Working Group on long-term Cooperative Action under the Convention. Accessed 26 October 2012. http://unfccc.int/files/meetings/cop_16/application/pdf/cop16_lca.pdf.

42 National Development and Reform Commission, China's Policies and Actions for Addressing Climate

Change - the Progress Report 2009 (Beijing: National Development and Reform Commission, 2009).
} 
Article published as:

Guo, X., Marinova, D., Hong, J. (2013) China's shifting policies towards sustainability: a low-carbon economy and environmental protection, Journal of Contemporary China, 22(81): 428-445

potentially being able to meet the $\mathrm{CO}_{2}$ reduction goal in a decade and a major component of this are international cooperation and widespread environmental education.

\section{International Cooperation}

Tackling the challenges of global climate change will need international cooperation and commitment. In order to achieve a low-carbon economy and sustainable development, China has widely cooperated with many developed countries at the provincial and national level, such as Singapore, USA and Australia. For example, with UNDP's support, many provincial governments had initiated provincial climate change programs and some of them had established climate change divisions within their administration. By the same time, the ability of provincial governments has been improved to implement adequately national climate change policies. ${ }^{43}$

There were a total of 287 cities at prefecture level of China in 2009, which cover 29\% of the country's population ${ }^{44}$. China's urban environment is currently generating $62 \%$ of $\mathrm{GDP}^{45}$ but is also struggling with severe pollution problems related to air and water quality, waste treatment, rubbish and sewage disposal, and overall environmental protection ${ }^{46}$. In April 2011, Australia and China agreed to strengthen their cooperation for the development of low-carbon cities in order to tackle global climate change ${ }^{47}$. Further insights, examples and cooperation for the development of a low-carbon economy in the cities are being sought from other Asian countries, such as Japan and South Korea, as well as from US and Europe.

\footnotetext{
${ }^{43}$ United Nations Development Programme (UNDP), UNDP in Action 2009/2010: Delivering on Commitments, 2010. Accessed 26 October 2012.

http://www.undp.org/content/india/en/home/library/poverty/undp_in_action_20092010deliveringoncommitment s.html.

${ }^{44}$ National Bureau of Statistics of China, China Statistic Yearbook 2010 (Beijing: China’s Statistics Press, 2010).

${ }^{45}$ Ibid.

${ }^{46}$ China Struggling to Control Urban Pollution Accessed 26 October 2012. http://www.china.org.cn/archive/2007-06/12/content_1213639.htm.

${ }^{47}$ Australia, China to Cooperate in Developing Low Carbon Cities. Accessed 26 October 2012. http://www.ensnewswire.com/ens/apr2011/2011-04-01-01.html.
} 
Article published as:

Guo, X., Marinova, D., Hong, J. (2013) China's shifting policies towards sustainability: a low-carbon economy and environmental protection, Journal of Contemporary China, 22(81): 428-445

China experienced enormous international interest in the implementation of clean development mechanism (CDM) projects. Since the Kyoto Protocol formally became effective on 16 February 2005, many developed countries have been seeking any possible opportunities to cooperate on CDM projects with developing countries pursuing mutual benefits. ${ }^{48}$ China attracted the most attention and the largest number of projects (see Figure $6)$.

[Insert Figure 6 here]

It is believed that CDM plays a very important role in assisting developing countries in the transition towards a low-carbon future and tackling climate change. ${ }^{49}$ The spirit of $\mathrm{CDM}$ is to encourage mutually beneficial transfer of advanced technologies and further technology development and management opportunities for the less developed regions of the world. ${ }^{50}$ China is proving to be the most attractive location for CDM projects because of its fast economic development, open door investment policy, political stability, high educational and technological standards and reliable infrastructure. On the other hand, certain regions, particularly the underdeveloped western provinces of the country need more development opportunities.

From the 2010 CDM registration, the countries with the largest number of projects were China, India, Brazil and Mexico with China providing a home to a staggering 39\% of all

\footnotetext{
${ }^{48}$ Weijun Gao, Nan Zhou, Haifeng Li and Daniel M Kammen, Possibility and Potential of Clean Development Mechanisms in China, Environmental Research Letters, 2 (October-December 2007), 044005 (8pp) doi:10.1088. ${ }^{49}$ Öko-Institut WWF background Note to the Report "Is the CDM fulfilling its Environmental Objectives? An Evaluation of the CDM and Options for Improvement”, 2007. Accessed 26 October 2012. http://assets.panda.org/downloads/cdm_report_wwf_background_paper.pdf.

${ }^{50}$ Md. Rabiul Amin and Dora Marinova, Technology Transfer and Sustainable Development through CDM: Bangladesh, Potentials for Clean Development Mechanism (CDM) in Developing Countries: the Case Study of Bangladesh (Berlin: VDM Verlag, 2009)
} 
Article published as:

Guo, X., Marinova, D., Hong, J. (2013) China's shifting policies towards sustainability: a low-carbon economy and environmental protection, Journal of Contemporary China, 22(81): 428-445

projects. The Chinese market has been developing dramatically and its global share has risen to more than a third from only $8 \%$ in $2006 .{ }^{51}$ The considerable location of CDM projects in China since the very first project (the Long Yuan wind farm project in Inner Mongolia registered in $2005^{52}$ ), demonstrates the shifts of the country towards a low-carbon economy with the assistance of the developed economies. China has formed national coordinating groups for climate change, CDM Designated National Authorities and projects auditing boards, which deal with project application, auditing and management. At the same time, the government has formulated a series of policies and regulations for the CDM market. Within just a few years, China’s CDM market has experienced a repaid development and maintained a sustained interest from investors. ${ }^{53}$

Figure 7 presents the trend in CDM projects approved by the Chinese government by October 2010, when the number of projects reached $2571 .^{54}$ In 2005, the CDM market in China was still in a primary developmental stage (with only 6 projects approved in the fourth quarter) but in 2006, it grew quickly and 237 new projects were added. In 2007, the CDM market continued to develop even faster and the number of the CDM projects approved in the third quarter was more than the 2006 total. In 2008 and 2009, due to the uncertainty about the CDM market in the post-Kyoto Era and the global economic crisis, the number of CDM projects approved has dropped. It only marginally improved throughout 2010. Nevertheless, a total of 2571 CDM projects were approved by the end of 2010. China's CDM market has emerged positively and steadily making a contribution to building China's low-carbon economy.

\footnotetext{
${ }^{51}$ United Nations Framework Convention on Climate Change (UNFCCC), CDM Statistics, 2010. Accessed 6 June 2010. http://cdm.unfccc.int/Statistics/Registration/NumOfRegisteredProjByHostPartiesPie.

${ }^{52}$ Project 0064 : Huitengxile Windfarm Project. Accessed 26 October 2012. http://cdm.unfccc.int/Projects/DB/TUEV-SUED1113481234.64/view

${ }^{53}$ National Development and Reform Commission, Clean Development Mechanism in China (2012). Accessed 26 October 2012. http://cdm.ccchina.gov.cn/web/index.asp.

${ }^{54}$ Ibid.
} 
Article published as:

Guo, X., Marinova, D., Hong, J. (2013) China's shifting policies towards sustainability: a low-carbon economy and environmental protection, Journal of Contemporary China, 22(81): 428-445

\section{[Insert Figure 7 here]}

Irrespective of the prospects for China in the post-Kyoto market, the country's future owners of CDM projects will be provided a lot of opportunities for improving their technologies but they will also have to tackle challenges such as how to finance and properly manage these activities. China is likely to appear as the real winner in the global CDM arena as well as in its steps forward to a low-carbon economy. While the CDM arena is largely driven by initiatives from the West in a supportive governmental framework, the groundwork for the low-carbon economy in China is in the hands of its environmental education system.

\section{Environmental Awareness and Education towards a Low-Carbon Economy in China}

The massive carbon emissions generated by China require its citizens and business people to have a sound level of environmental awareness as well as access to transparent environmental information $^{55}$. Many Chinese people who have been directly affected by pollution and other environmental deterioration have already started the fight to protect their interests ${ }^{56}$. Although China has basically established a relatively complete environmental management system, this country is still in the infancy of effective implementation of environmental management laws and regulations. This is partially due to the nature of the legislation which is quite broad and complex ${ }^{57}$. In order to achieve environmental protection objectives, deeper environmental publicity and education is needed to mobilize the public to participate in

\footnotetext{
${ }^{55}$ Wanxin Li, Duoduo Li, 'Environmental Information Transparency and Implications for Green Growth in China', Public Administration and Development 32, (2012), pp. 324-334.

${ }^{56}$ Benjamin Van Rooij, 'The People vs. Pollution: Understanding citizen action against pollution in China', Journal of Contemporary China 19(63), (2010), pp. 55-77.

${ }^{57}$ Danny Marks, 'China's climate change policy process: Improved but still weak and fragmented', Journal of Contemporary China 19(67), (2010), pp. 971-986.
} 
Article published as:

Guo, X., Marinova, D., Hong, J. (2013) China's shifting policies towards sustainability: a low-carbon economy and environmental protection, Journal of Contemporary China, 22(81): 428-445

environmental protection and achieving a low-carbon economy. In 1996, China carried out the Platform for Action, the National Environmental Publicity and Education (1996-2010) program. ${ }^{58}$ This action was strengthened further in 2001 and $2006 .{ }^{59}$

These are important steps for the Chinese government to start paying serious attention to the country's environmental education. The purpose and significance of the Platform for Action are represented in the fact that the Chinese government recognizes that the level of environmental awareness is a measure of the degree of civilization in a country. With the increase in the educational level of the Chinese people, and more and more of them accessing higher education in particular ${ }^{60}$, their understanding of environmental issues and environmental consciousness are improving. Achieving a certain level of public environmental awareness is vital for China's shift towards sustainable development and a low-carbon economy.

In the formal educational system of China, the environmental curriculum desperately requires further strengthening. The lack of environmental knowledge is an important reason for many Chinese citizens and organizations to have poor awareness of the need for environmental protection and solving of environmental problems, such as land erosion, air, soil and water pollution. ${ }^{61}$ Although environmental awareness has been increasing as the Chinese government has undertaken proactive activities, efforts are called for from Chinese governmental agencies and industry in delivering better environmental education in order to achieve a low-carbon economy.

\footnotetext{
${ }^{58}$ National Environmental Protection Bureau, the CPC Central Committee Propaganda Department, the National Education Committee, Platform for Action, the National Environmental Publicity and Education (1996-2010), Beijing, 1996 (in Chinese). Accessed 6 August 2010. http://www.chinalawedu.com/news/1200/22598/22603/22683/2006/3/sh 24812801213 6002546-0.htm. 59 Ibid.

${ }^{60}$ Shujie Yao, Bin Wu, Fang Su, Jianling Wang, 'The impact of higher education expansion on social justice in China: A spatial and inter-temporal analysis', Journal of Contemporary China 19(67), (2010), pp. 837-854.

${ }^{61}$ Jin Hong, Xiumei Guo and Dora Marinova, "NGOs and Environmental Education in China”, in Sharing Wisdom for Our Future: Environmental Education in Action, ed. Sandra Wooltorton and Dora Marinova (Sydney: Australian Association for Environmental Education, 2006, pp. 353-362).
} 
Article published as:

Guo, X., Marinova, D., Hong, J. (2013) China's shifting policies towards sustainability: a low-carbon economy and environmental protection, Journal of Contemporary China, 22(81): 428-445

Environmental non-governmental organizations (NGOs) have been carrying out a large number of activities to promote environmental education in China. They have been successful in influencing China's system of environmental education as well as environmental policy making including through liaising with international NGOs ${ }^{62}$. A good example of this is the adoption of the textbook of Environmental Education Implementation Guideline for Middle and Primary Schools developed with the assistance of WWF (World Wide Fund for Nature, formerly World Wildlife Fund) ${ }^{63}$. The Chinese government and industry need to cooperate with the numerous NGOs ${ }^{6465}$ and volunteer organizations ${ }^{66}$ to build a sound base of supporters and public trustees and to encourage public participation in environmental protection. Most importantly, it is crucial to have a bigger role for government in environmental education, legislation and protection for the adoption of a low-carbon economy.

\section{National Sustainability Strategy for China}

China's new $12^{\text {th }}$ Five-Year Plan outlines a more balanced model of development which aims at continuing the stable and relatively fast economic growth and improving the prosperity of the country's citizens, but also for achieving these in a healthier ecological environment. There is more research evidence emerging that wealthier parts of the country have already started to invest in more sustainable communities, including attention to ecological health ${ }^{67}$

\footnotetext{
62 Jie Chen, 'Transnational environmental movement: impacts on the green civil society in China', Journal of Contemporary China 19(65), (2010), pp. 503-523.

${ }^{63}$ Ibid.

${ }^{64}$ Jin Hong, Xiumei Guo and Dora Marinova, "NGOs and Environmental Education in China”, in Sharing Wisdom for Our Future: Environmental Education in Action, ed. Sandra Wooltorton and Dora Marinova (Sydney: Australian Association for Environmental Education, 2006, pp. 353-362).

${ }^{65}$ Rob Eifird, 'Learning the Land Beneath Our Feet: NGO 'Local Learning Materials' and Environmental Eeducation in Yunnan Province’, Journal of Contemporary China 21(76), (2012), pp. 569-584.

${ }^{66}$ Outi Luova, 'Community Volunteers' Associations in Contemporary Tianjin: Multipurpose Partners of the Party-State’, Journal of Contemporary China 20(72), (2011), pp. 773-794.

${ }^{67}$ Jiuchang Wei, Dingtao Zhao and Dora Marinova, What Determines a Community to Choose the Pathway to
} 
Article published as:

Guo, X., Marinova, D., Hong, J. (2013) China's shifting policies towards sustainability: a low-carbon economy and environmental protection, Journal of Contemporary China, 22(81): 428-445

and also that the central government is redefining local economic progress priorities by adopting environmental indicators for evaluating progress ${ }^{68}$. This paper presented an analysis of recent economic development in China and the policy shift towards a more sustainable model. It emphasized China's role and responsibility as a global player as well as its willingness to become an active part of the global low-carbon economy through encouraging the location of CDM projects and major strategic policy targets. China is fast becoming a very attractive place not only for location of industry but also for technology development, including through large renewable energy investment ${ }^{69}$ and attracting returnee Chinese entrepreneurs educated in the best universities around the world ${ }^{70}$. This talent is likely to further demand and work towards improving the country’s environmental image.

Therefore China needs to significantly improve its domestic environmental record. Failure to do this will foster further social discontent ${ }^{71}$. Better environmental awareness and education are needed to reduce the pressure on energy resources due to the large and growing population, as well as environmental deterioration due to continuing industrialization, urbanization and land degradation.

China has made greater efforts particularly during its $11^{\text {th }}$ Five-Year Plan to tackle climate change and to adjust its response to the capacity of low-carbon economic development. It has also set high targets for its $12^{\text {th }}$ Five-Year Plan with economic growth slowed down to 7\% per year in order to accommodate for its energy and carbon

\footnotetext{
Sustainable Development in China?, Local Environment, 5, (2010), pp. 831-850.

${ }^{68}$ Wanxin Li and Paul Higgins, 'Controlling Local Environmental Performance: an analysis of three national environmental management programs in the context of regional disparities in China', Journal of Contemporary China, 22(81), (2013), this issue pp.??

${ }^{69}$ China's is the largest investor in renewable energy in the world, according to The Pew Charitable Trusts, Who's Winning The Clean Energy Race? 2010 Edition: G-20 Investment Powering Forward, 2010, http://www.pewenvironment.org/uploadedFiles/PEG/Publications/Report/G-20Report-LOWRes-FINAL.pdf

${ }^{70}$ Huiyao Wang, David Zweig and Xiaohua Lin, 'Returnee entrepreneurs: Impact on China's globalization process', Journal of Contemporary China 20(70), (2011), pp. 413-431.

${ }^{71}$ Guoguang Wu, China in 2010: Dilemmas of "Scientific Development", Asian Survey 51, (2011), pp. 18-32.
} 
Article published as:

Guo, X., Marinova, D., Hong, J. (2013) China’s shifting policies towards sustainability: a low-carbon economy and environmental protection, Journal of Contemporary China, 22(81): 428-445

intensity targets $^{72}$. The analysis presented here suggests that China is already well advanced in establishing a national sustainability strategy that builds around three major components: firstly, continuous encouragement of low-carbon economic projects; secondly, educational outreach to its population on sustainability issues; and thirdly, strengthening of its environmental protection (see Figure 8). It is a difficult task to achieve the proper integration of economic, environmental and social priorities but China seems to be challenging the rest of the world's community by showing leadership in changing the status quo.

[Insert Figure 8 here]

\footnotetext{
72 Joanna Lewis, 'Energy and Climate Goals of China's 12th Five-Year Plan’, 2011. Accessed 26 October 2012. http://www.pewclimate.org/international/factsheet/energy-climate-goals-china-twelfth-five-year-plan
} 
Article published as:

Guo, X., Marinova, D., Hong, J. (2013) China's shifting policies towards sustainability: a low-carbon economy and environmental protection, Journal of Contemporary China, 22(81): 428-445

Figure 1. Economic growth in China and Asia 2004-2011

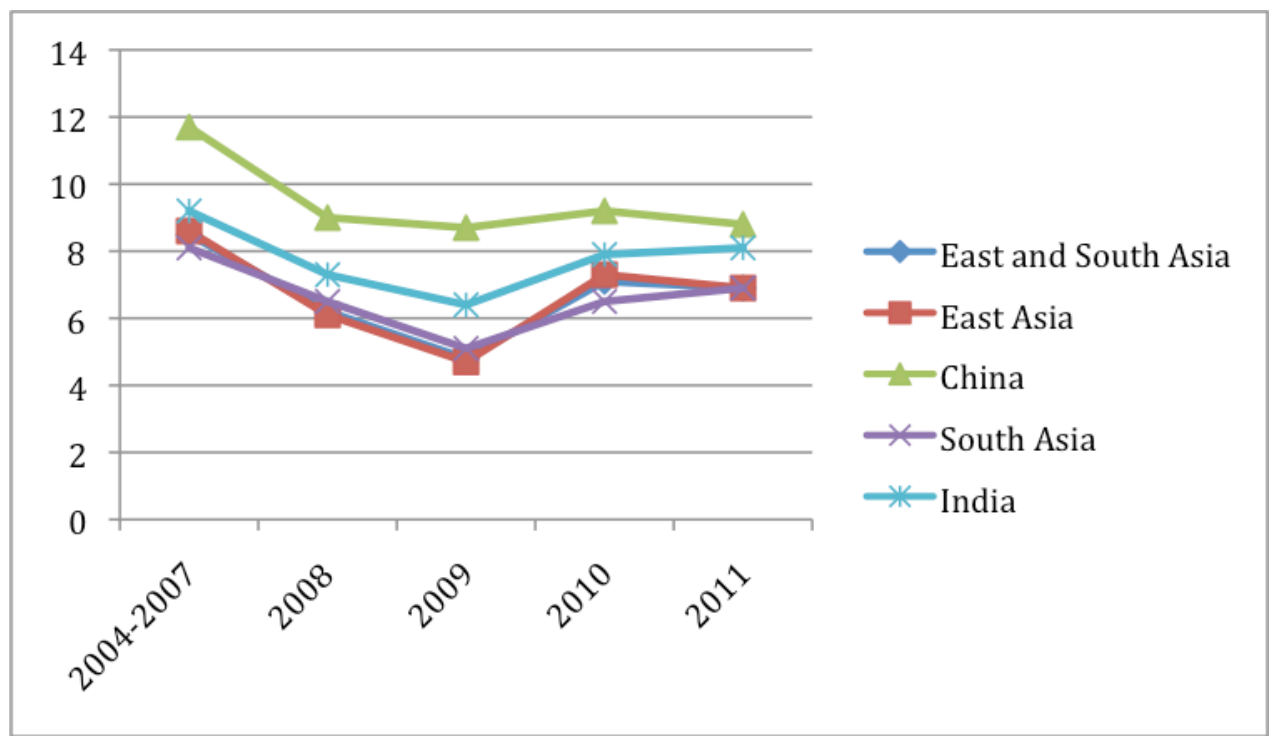

Source: Compiled from United Nations (2010) ${ }^{73}$

\footnotetext{
${ }^{73}$ United Nations World Economic Situation and Prospects 2010, New York, 2010. Accessed 26 October 2012. http://www.un.org/esa/policy/wess/wesp.html.
} 
Article published as:

Guo, X., Marinova, D., Hong, J. (2013) China's shifting policies towards sustainability: a low-carbon economy and environmental protection, Journal of Contemporary China, 22(81): 428-445

Figure 2. Total $\mathrm{CO}_{2}$ emissions per capita and GDP per capita for selected countries, 2010

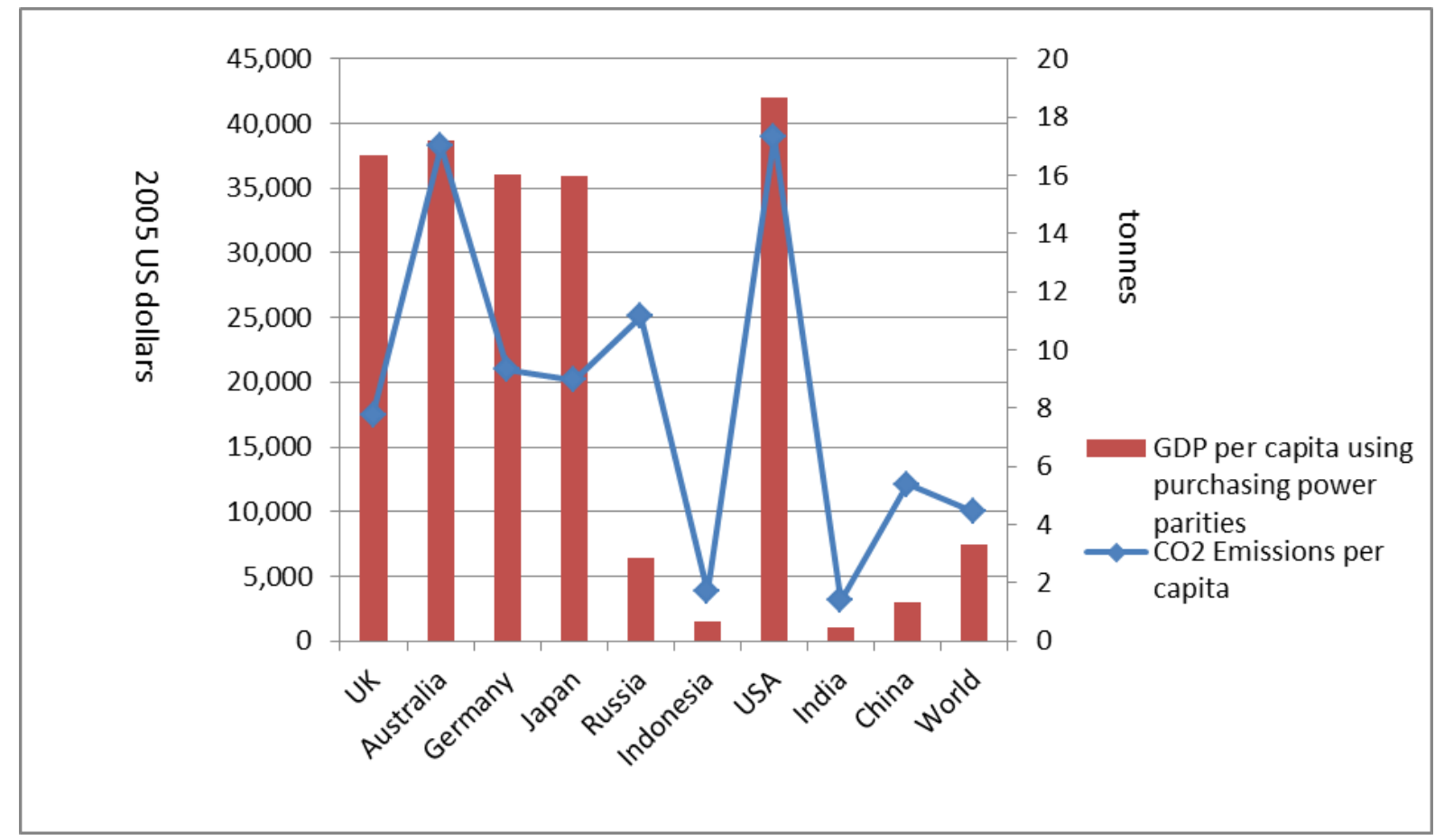

Source: Compiled from International Energy Agency (IEA) (2012) ${ }^{74}$.

\footnotetext{
${ }^{74}$ International Energy Agency, CO2 Emissions from Fuel Combustion. Accessed 25 October 2012. http://www.iea.org/publications/freepublications/publication/name,4010,en.html
} 
Article published as:

Guo, X., Marinova, D., Hong, J. (2013) China's shifting policies towards sustainability: a low-carbon economy and environmental protection, Journal of Contemporary China, 22(81): 428-445

Figure 3. $\mathrm{CO}_{2}$ emissions: selected countries (1971-2010)

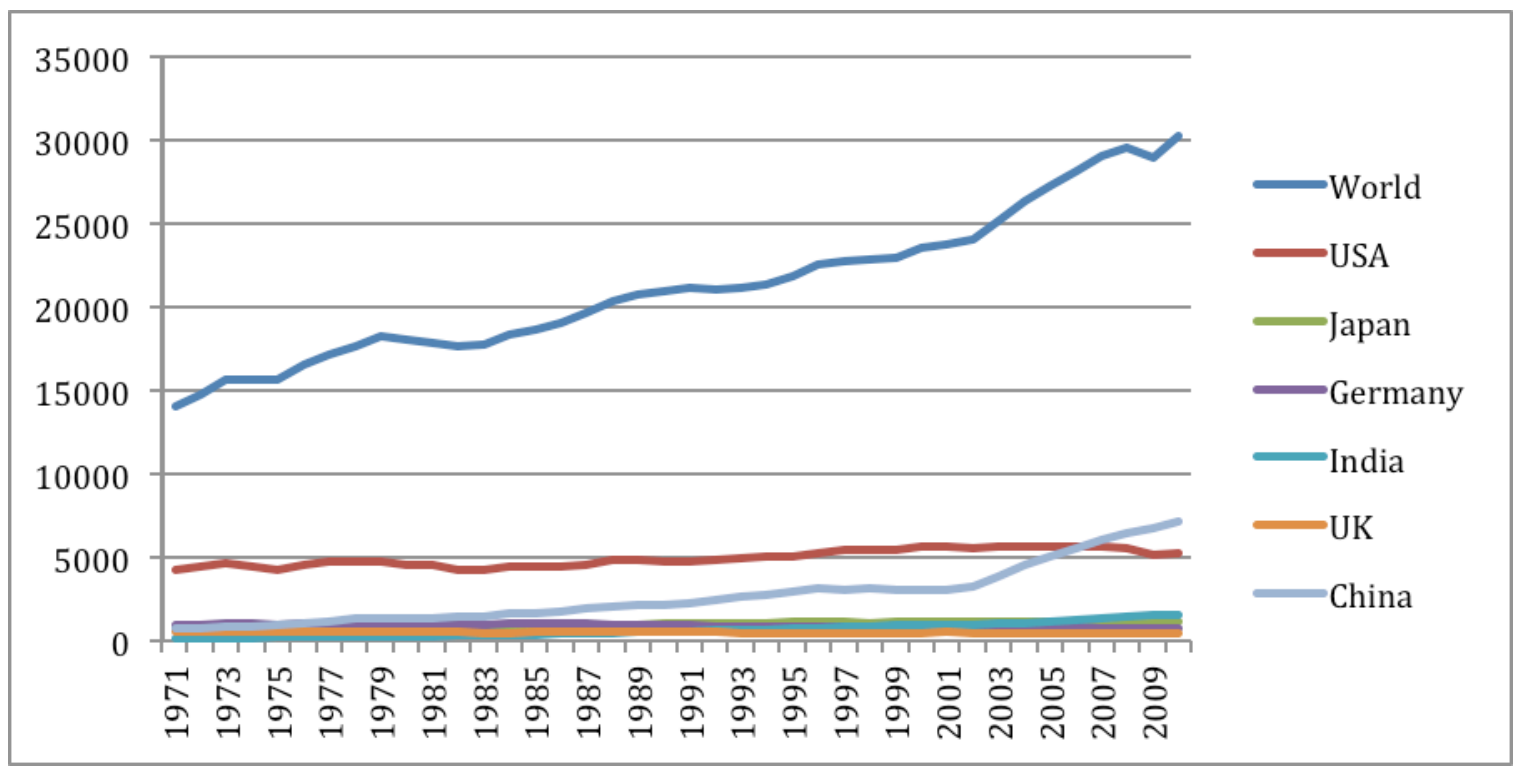

Source: Compiled from International Energy Agency (IEA) (2012) ${ }^{75}$

\footnotetext{
${ }^{75}$ International Energy Agency, CO2 Emissions from Fuel Combustion. Accessed 25 October 2012. http://www.iea.org/publications/freepublications/publication/name,4010,en.html
} 
Article published as:

Guo, X., Marinova, D., Hong, J. (2013) China's shifting policies towards sustainability: a low-carbon economy and environmental protection, Journal of Contemporary China, 22(81): 428-445

Figure 4. Population and carbon dioxide emissions per capita for selected countries, 2010

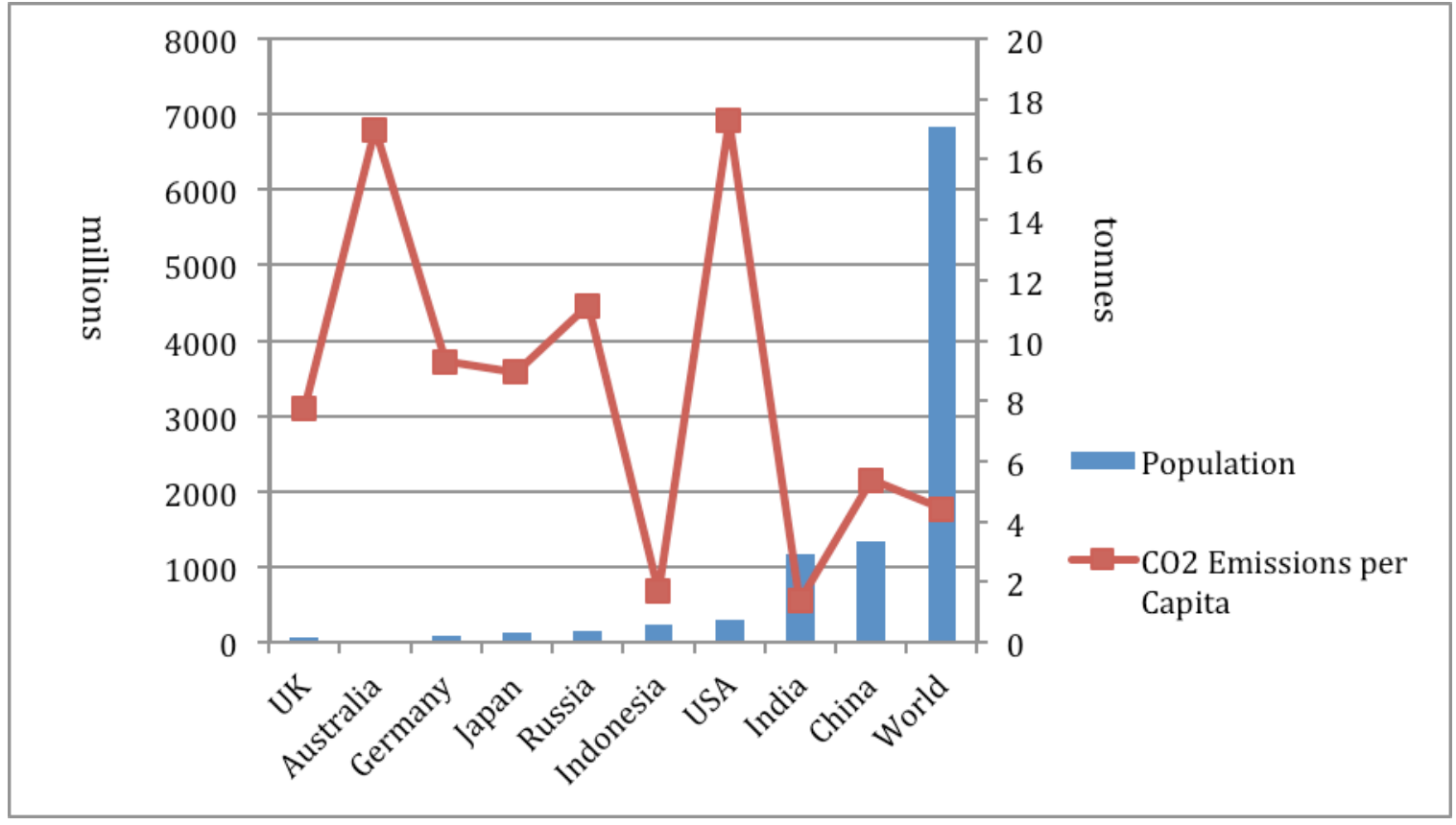

Source: Compiled from International Energy Agency (IEA) (2012) ${ }^{76}$

\footnotetext{
${ }^{76}$ International Energy Agency, CO2 Emissions from Fuel Combustion. Accessed 25 October 2012. http://www.iea.org/publications/freepublications/publication/name,4010,en.html
} 
Article published as:

Guo, X., Marinova, D., Hong, J. (2013) China's shifting policies towards sustainability: a low-carbon economy and environmental protection, Journal of Contemporary China, 22(81): 428-445

Figure 5. $\mathrm{CO}_{2}$ Emission intensity and $\mathrm{CO}_{2}$ emissions per capita, China, 1971 to 2010

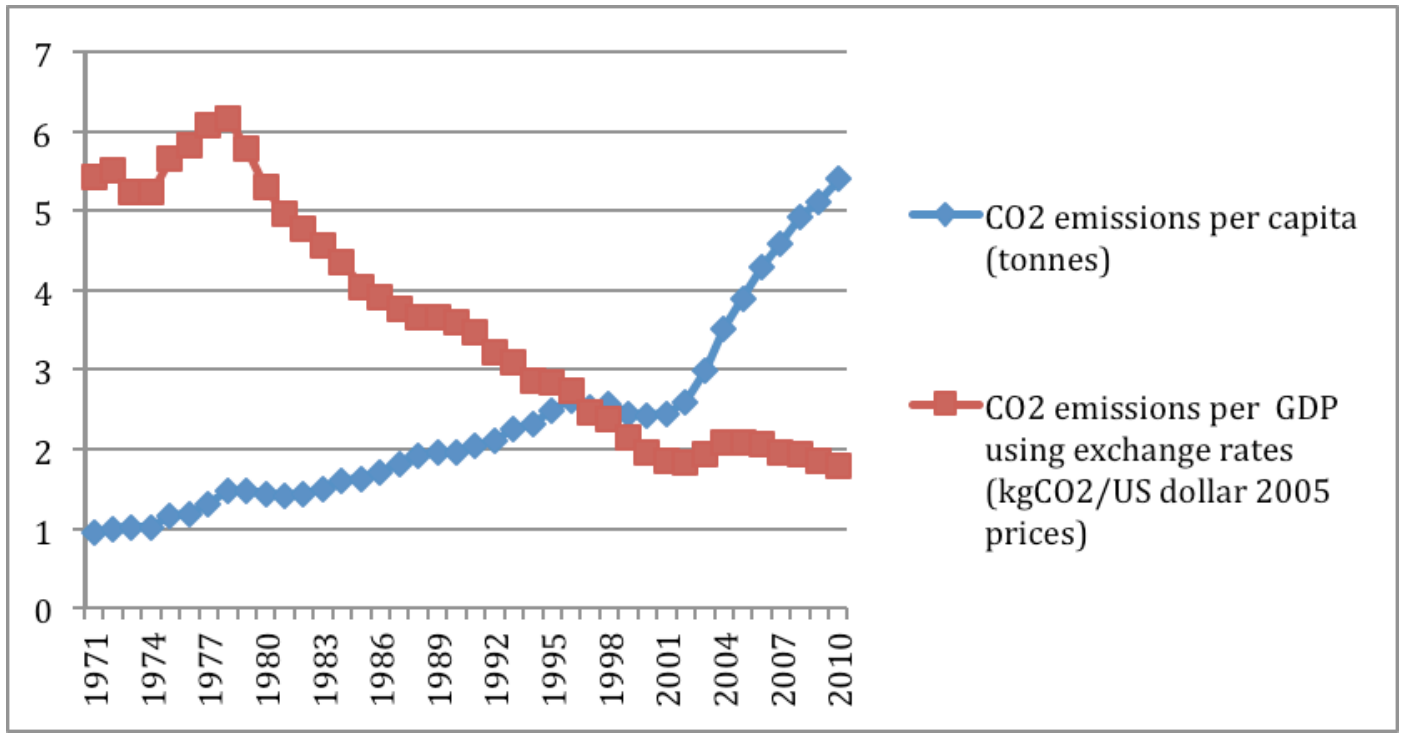

Source: Compiled from International Energy Agency (IEA) (2012) ${ }^{77}$

\footnotetext{
${ }^{77}$ International Energy Agency, CO2 Emissions from Fuel Combustion. Accessed 25 October 2012. http://www.iea.org/publications/freepublications/publication/name,4010,en.html
} 
Article published as:

Guo, X., Marinova, D., Hong, J. (2013) China's shifting policies towards sustainability: a low-carbon economy and environmental protection, Journal of Contemporary China, 22(81): 428-445

Figure 6. Registered CDM project activities by host party (total 4,777), 17 October 2012

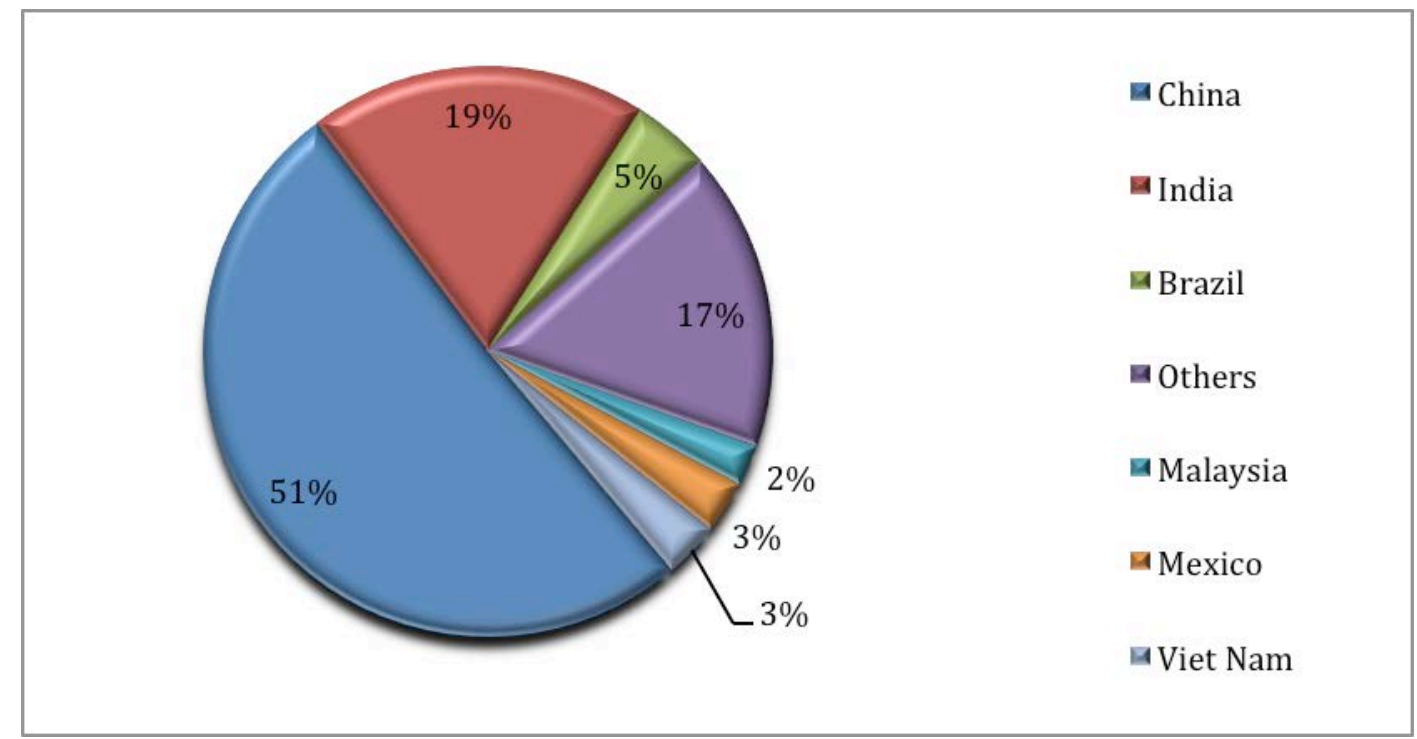

Source: Compiled from UNFCCC data ${ }^{78}$

\footnotetext{
${ }^{78}$ Accessed 26 October 2012. http://cdm.ccchina.gov.cn/web/NewsInfo.asp?NewsId=6345.
} 
Article published as:

Guo, X., Marinova, D., Hong, J. (2013) China's shifting policies towards sustainability: a low-carbon economy and environmental protection, Journal of Contemporary China, 22(81): 428-445

Figure 7. Trend of CDM projects approved by the Chinese Government,

December 2010

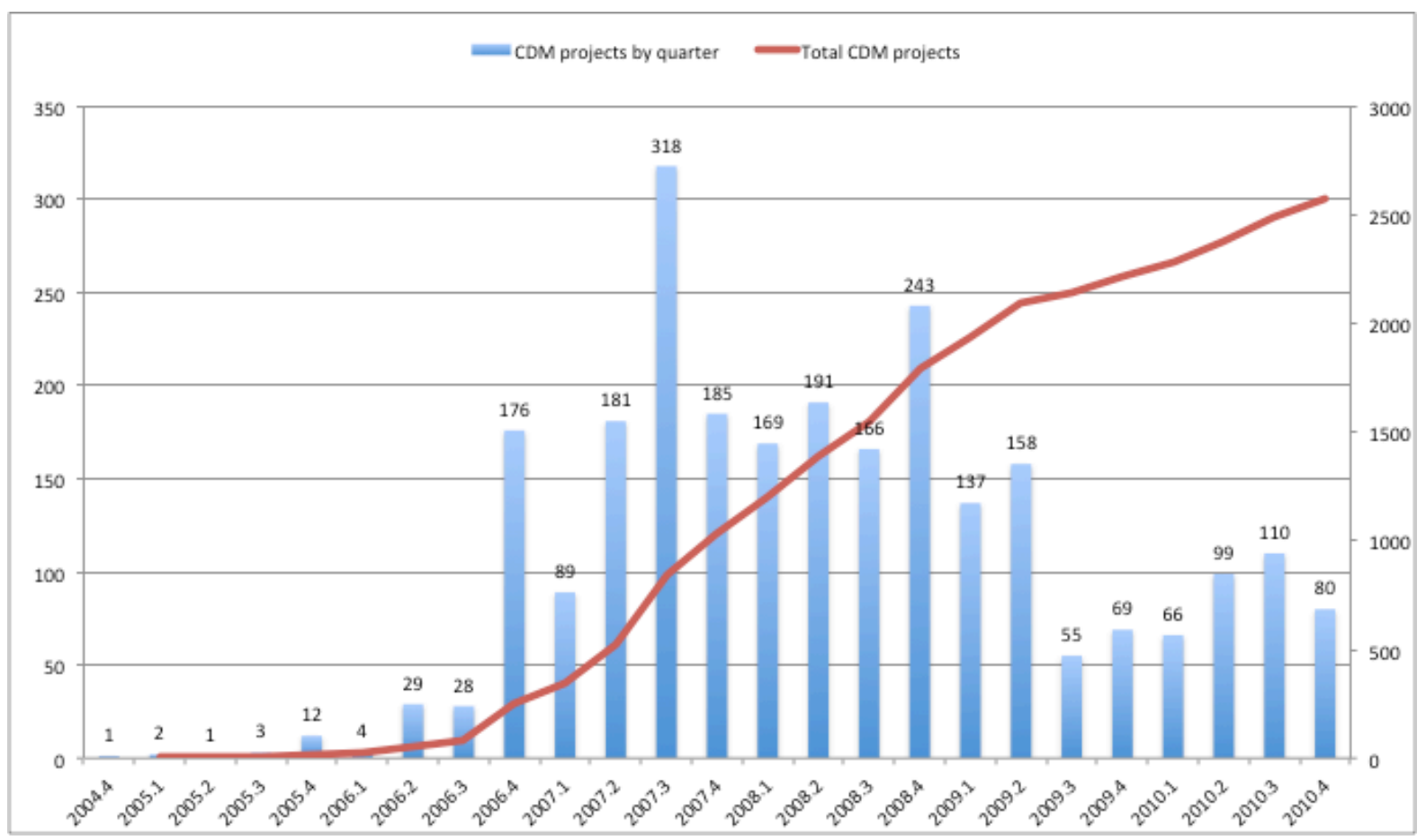

Source: National Development and Reform Commission (2010) ${ }^{79}$

${ }^{79}$ National Development and Reform Commission Clean Development Mechanism in China (2009), 2010. Accessed 26 October 2012. http://cdm.ccchina.gov.cn/web/index.asp. 
Article published as:

Guo, X., Marinova, D., Hong, J. (2013) China's shifting policies towards sustainability: a low-carbon economy and environmental protection, Journal of Contemporary China, 22(81): 428-445

Figure 8. China's National Sustainability Strategy

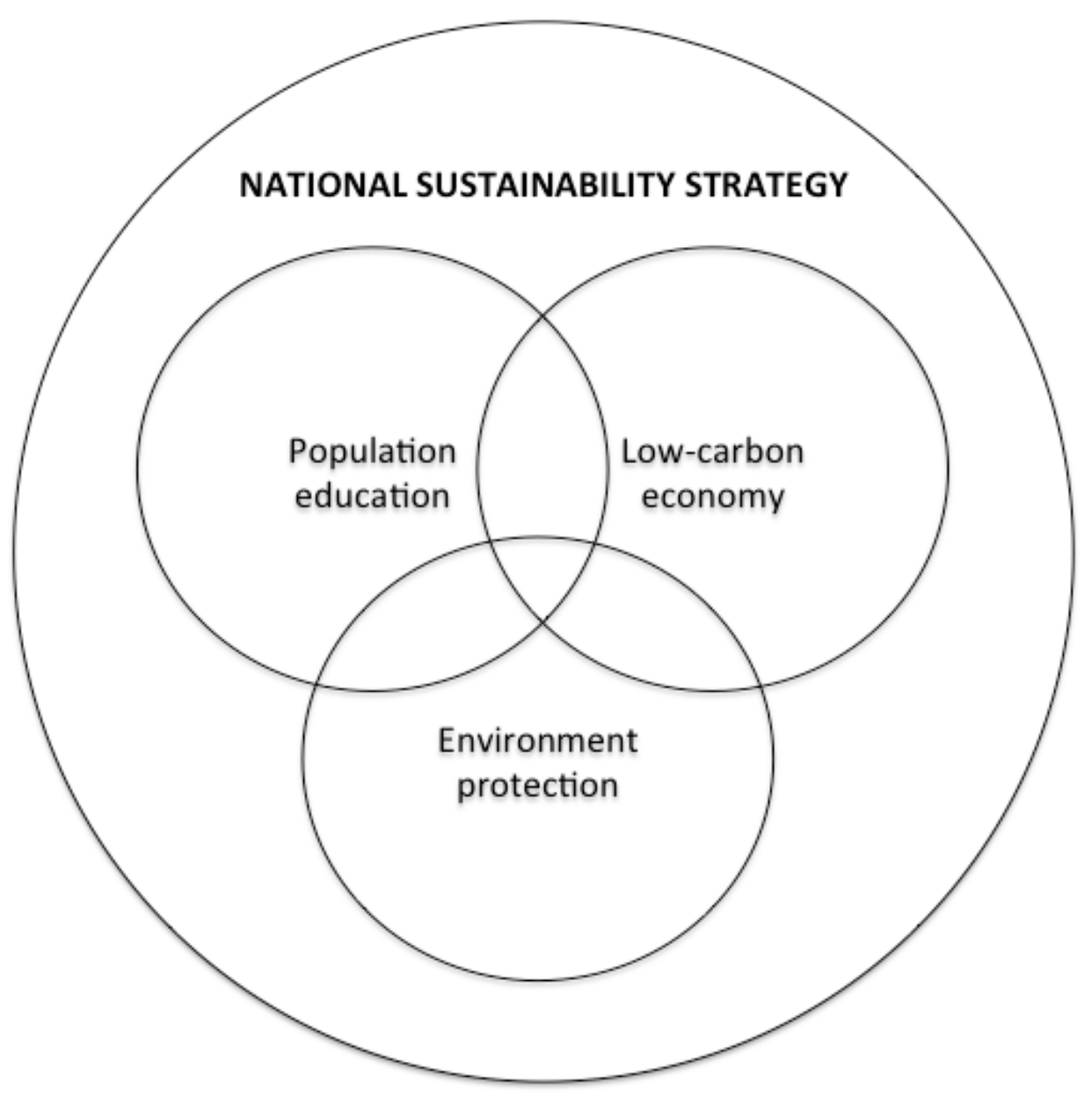


Article published as:

Guo, X., Marinova, D., Hong, J. (2013) China's shifting policies towards sustainability: a low-carbon economy and environmental protection, Journal of Contemporary China, 22(81): 428-445

Table 1. China's main targets for the $11^{\text {th }}$ and $12^{\text {ve }}$ Five-Year Plans

\begin{tabular}{|c|c|}
\hline $1^{\text {th }}$ Five-Year Plan (2006-2010) & 12th Five-Year Plan (2011-2015) \\
\hline \multicolumn{2}{|c|}{ Economic Growth } \\
\hline $\begin{array}{l}--7.5 \% \text { annual GDP growth (from } 18.2 \\
\text { trillion yuan in } 2005 \text { to } 26.1 \text { trillion yuan in } \\
2010 \text { ) }\end{array}$ & $\begin{array}{l}\text {-- Lower annual growth target of } 7 \% \text { over the } \\
\text { five-year period }\end{array}$ \\
\hline $\begin{array}{l}\text {-- } 6.6 \% \text { per capita GDP annual growth (from } \\
13,985 \text { yuan in } 2005 \text { to } 19,270 \text { yuan in } 2010 \text { ) }\end{array}$ & $\begin{array}{l}\text {-- 7\% per capita GDP annual growth over the } \\
\text { five-year period }\end{array}$ \\
\hline $\begin{array}{l}\text {-- The } 7.5 \% \text { GDP growth target was not } \\
\text { realized; instead the country's economy grew } \\
\text { at an annual rate of around } 10 \% \text { from } 2006 \text { to } \\
2010\end{array}$ & $\begin{array}{l}\text {-- It will be challenging for China to slow } \\
\text { down its economic growth, particularly as } \\
\text { previous evidence points to the contrary }\end{array}$ \\
\hline \multicolumn{2}{|c|}{ Economic Structure } \\
\hline $\begin{array}{l}\text {-- Share of service industry's value added to } \\
\text { GDP up from } 40.3 \% \text { in } 2005 \text { to } 43.3 \% \text { in } \\
2010\end{array}$ & $\begin{array}{l}\text {--Share of service industry's value added to } \\
\text { GDP up from } 43 \% \text { in } 2010 \text { to } 47 \% \text { in } 2015\end{array}$ \\
\hline $\begin{array}{l}\text {-- Share of R\&D spending out of total GDP } \\
\text { up from } 1.3 \% \text { in } 2005 \text { to } 2 \% \text { in } 2010\end{array}$ & $\begin{array}{l}\text {-- Share of R\&D spending out of total GDP } \\
\text { up from } 1.75 \% \text { in } 2010 \text { to } 2 \% \text { in } 2015\end{array}$ \\
\hline $\begin{array}{l}\text {-- Urbanization rate up from } 43 \% \text { in } 2005 \text { to } \\
47 \% \text { in } 2010\end{array}$ & $\begin{array}{l}\text {-- Urbanization rate up from } 47.5 \% \text { in } 2010 \\
\text { to } 51.5 \% \text { in } 2015\end{array}$ \\
\hline \multicolumn{2}{|c|}{ Resources and Environment } \\
\hline $\begin{array}{l}\text {-- Energy consumption per unit of GDP } \\
\text { down } 20 \% \text { in five years }\end{array}$ & -- $16 \%$ reduction in energy intensity \\
\hline $\begin{array}{l}\text {-- Water consumption per unit of industrial } \\
\text { value added down } 30 \% \text { in five years }\end{array}$ & $\begin{array}{l}\text {-- Water consumption per unit of industrial } \\
\text { added value down } 30 \% \text { in five years }\end{array}$ \\
\hline $\begin{array}{l}\text {-- Coefficient of effective water use for } \\
\text { irrigation up from } 0.45 \% \text { in } 2005 \text { to } 0.5 \% \text { in } \\
2010\end{array}$ & $\begin{array}{l}\text {-- Coefficient of effective water use for } \\
\text { irrigation up from } 0.5 \% \text { in } 2010 \text { to } 0.53 \% \text { in } \\
2015\end{array}$ \\
\hline $\begin{array}{l}-- \text { Total discharge of major pollutants down } \\
10 \% \text { in five years }\end{array}$ & $\begin{array}{l}\text {--Total discharge of major pollutants down } 8 \\
\text { to } 10 \% \text { in five years }\end{array}$ \\
\hline -- Forest coverage up from $18.2 \%$ in 2005 to & -- Forest coverage up from 20.36\% in 2010 \\
\hline
\end{tabular}


Article published as:

Guo, X., Marinova, D., Hong, J. (2013) China's shifting policies towards sustainability: a low-carbon economy and environmental protection, Journal of Contemporary China, 22(81): 428-445

\begin{tabular}{|l|l|}
\hline $20 \%$ in 2010 & to $21.66 \%$ in 2015 \\
$\begin{array}{l}\text {-- Rate of comprehensive use of solid } \\
\text { industrial waste up from } 55.8 \% \text { in } 2005 \text { to } \\
60 \% \text { in } 2010\end{array}$ & $\begin{array}{l}\text {-- Increasing non-fossil energy to } 11 \% \text { of } \\
\text { total energy use }\end{array}$ \\
$\begin{array}{l}\text {-- Total average of cultivated land down from } \\
122 \text { million hectares in } 2005 \text { to } 120 \text { million } \\
\text { in } 2010\end{array}$ & $-17 \%$ reduction in carbon intensity \\
\hline
\end{tabular}

Sources: Chinese Government, $2006^{80}$ and $2011^{81}$

\footnotetext{
${ }^{80}$ Chinese Government's Official Web Portal (2006b), Facts and Figures: China's main targets for 2006-2010. Accessed 26 October 2012. http://www.gov.cn/english/2006-03/06/content_219504.htm.

${ }^{81}$ Accessed 26 October 2012. http://news.xinhuanet.com/politics/2011-03/16/c_121193916_4.htm.
} 
Article published as:

Guo, X., Marinova, D., Hong, J. (2013) China's shifting policies towards sustainability: a low-carbon economy and environmental protection, Journal of Contemporary China, 22(81): 428-445

Table 2. China's major measures and policies for environmental protection

\section{During the Cultural Revolution Period}

$1971 \quad$ United Nations’ General Assembly votes to seat representatives of the PRC

1972 Chinese representatives attend the First United Nations Conference on the Human Environment held in Sweden

1973 The first environmental protection meeting is being held in Beijing

1974 State Council Leadership Group of Environmental Protection and Water resources protection groups are established

\section{Since Economic Reform and Open Door Policies}

The first Environmental Protection Law is passed

China joins UNEP's Global Environment Monitoring System, the International Registry of Potentially Toxic Chemicals and International Environmental Information Systems

1983 State Council Leading Group Office of Environmental Protection is upgraded to State Council Environmental Protection Committee

The second national environmental protection meeting is held and the Path to Environmental Protection with Chinese Characteristics becomes a policy.

$1984 \quad$ Water Pollution Prevention and Control Law passed

Water Pollution Control Act 1984 passed (modified in 1996 and 2008)

The Water Resources Law enacted in 1988, amended and effective in 2002

Ten major measures for China's environment and development are established with the belief that sustainable development is the only choice for China

Chinese Environmental Protection Century Tour Campaign is initiated

China's Agenda 21 (White Paper on China’s Population, Environment and

Development in the $21^{\text {st }}$ Century) is adopted

1995 Law on the prevention and control of atmospheric pollution, prevention of air pollution from burnt coal, control of $\mathrm{SO}_{2}$ and acid rain is adopted (amended and effective in 2000)

1996 China's National Economic and Social Development's $9^{\text {th }}$ Five-Year Plan and Goals for Vision 2010 with the implementation of Sustainable Development as a major Strategy for Modernization are adopted

Platform for Action, the National Environmental Publicity and Education (1996-2010) program are adoptedWater Pollution Prevention Law is updated

The State Council Decision on Issues Concerning Environmental Protection (10 goals including Environmental Law Enforcement) is made

Acid rain control and sulfur dioxide control zones are designated

Sulfur dioxide emission fees are established

State Council Notice issued on the protection of forest resources to stop deforestation and reckless use and encourage forest reclamation

Construction Project Environmental Protection Management Regulations, including an environmental impact assessment system, are implemented

1999 Management Regulation for Hazardous Waste Transfer is adopted

2000 The PRC Air Pollution Prevention and Control Law is adopted

Regulation of Water Pollution Prevention and Control Law is implemented

China Becoming a Global Player 
Article published as:

Guo, X., Marinova, D., Hong, J. (2013) China's shifting policies towards sustainability: a low-carbon economy and environmental protection, Journal of Contemporary China, 22(81): 428-445

2007

China's first National Report on Climate Change Assessment is issued China National Climate Change Program (China issued a national plan to address climate change as the first developing country)China's stance on climate change announced at APEC meeting China's Energy Conditions and Policies are published

2008 WWF launches China's low-carbon city development project: Baoding and

2009 Shanghai are the first pilot cities selected China's first target on reducing the intensity of $\mathrm{CO}_{2}$ emissions per unit of GDP in 2020 by $40-45 \%$ compared to 2005 level. Is announced

$12^{\text {th }}$ Five-Year Plan is adopted. It includes important targets to be achieved by the
end of the Plan: $17 \%$ reduction in carbon intensity $\left(\mathrm{CO}_{2}\right.$ e per US $\$$ of GDP $) ; 11 \% \mathrm{~s}$ hare of non-fossil fuel energy; $16 \%$ reduction in energy intensity.

Source: various sources 